\title{
State-of-the-art overview on biological treatment for CRSWNP*
}

\section{P.W. Hellings ${ }^{1,2,3}$, E. Verhoeven', W.J. Fokkens ${ }^{3}$}

Department of Otorhinolaryngology, Head \& Neck Surgery, University Hospitals Leuven, Leuven, Belgium

Department of Otorhinolaryngology, University Hospital Ghent, Laboratory of Upper Airway Research, Ghent, Belgium

${ }^{3}$ Department of Otorhinolaryngology, Head \& Neck Surgery, Academic Medical Centre (AMC), Amsterdam, the Netherlands
Rhinology 59: 2, 151 - 163, 2021

https://doi.org/10.4193/Rhin20.570

*Received for publication:

November 9, 2020

Accepted: December 13, 2020

\begin{abstract}
Background: The majority of patients with uncontrolled severe CRSWNP, asthma and atopic dermatitis share a similar T helper 2 type inflammation linked to their underlying phenotype. This discovery has triggered new research around treatments targeting specific cytokines driving inflammation in CRSwNP like IL-4, IL-13, IL-5 and IgE. Biologicals are increasingly tested as additional treatment for patients suffering from severe chronic rhinosinusitis with nasal polyps (CRSwNP). Their efficacy has been demonstrated in multiple studies. All studies differ in terms of baseline characteristics of included patients and outcome parameters analysed.
\end{abstract}

Aims: A comparative analysis of the efficacy of reported biologicals for CRSWNP based on the published data for phase 2 and 3 studies. The aim was to provide a comprehensive overview across the different biologicals and outcome parameters.

Methods: In a first step we critically selected out of all available phase 2 and 3 clinical trials the ones containing the most rigorous and compatible study designs. Meaning studies that comply with a need for a clear definition of CRSwNP, at least two administration doses, comparable timeframes and the same outcome parameters studied. This assessment was performed using a PRISMA search. We retained 7 studies with significant data for dupilumab, mepolizumab and omalizumab. In a second step the effect-sizes of treatment with those biologicals were compared for the most important outcome parameters both patient relevant (nasal congestion, smell loss and SNOT-22 scores) and patient irrelevant (CT scan Lund-Mackay, smell test and nasal polyp scores). Therapy duration of 16 to 25 weeks was chosen for evaluation of efficacy.

Results: A direct comparison of efficacy between dupilumab, mepolizumab and omalizumab is challenging given differences in inclusion criteria, outcome parameters and time-points of analyses. We have been able to conclude that effect sizes of dupilumab, mepolizumab and omalizumab seem large enough to reflect a major reduction in symptom burden as experienced by patients suffering from refractory CRSWNP. The effect size of dupilumab on both patient relevant and patient irrelevant parameters of smell loss are clearly significant and reflect the clinical experience of major reduction of smell impairment in treated patients.

Conclusion: Despite the heterogeneity of protocols, dosages and time-points of analyses of biological trials in CRSwNP, this overview highlights outcomes of biological treatment in CRSWNP in a comprehensive way. Real-life registries, comparative trials and/ or endotype-driven treatment plans are needed to provide the answers to the multiple questions that are still open today.

Key words: chronic rhinosinusitis with nasal polyps (CRSwNP), treatment, biologicals, type 2

\section{Introduction}

EPOS2020 (1) provides the ENT community with guidance for better care of CRS, including integrated care pathways. The treatment plan for patients with severe uncontrolled CRSwNP has recently been enriched by the option of biological treatment. The current treatment of CRSwNP consists of anti-inflammatory treatment with corticosteroids in nasal or oral formulation, supplemented with oral antibiotics. When medical treatment 
fails, sinus surgery is advocated ${ }^{(1)}$. The novel treatment option with biologicals targets one or more biomarkers of CRSwNP, i.e. IL-4, IL-13, IL-5 and IgE ${ }^{(2,3)}$, which drive the inflammation in the sinonasal mucosa in CRSwNP. As a subgroup of CRSwNP remain uncontrolled despite surgery and/or oral corticosteroids ${ }^{(4)}$, new therapeutic options are embraced by the Rhinology community and by the patients given the recent publications with proven efficacy of biological molecules in multi-center trials ${ }^{(5)}$. In 2019, the EUFOREA expert team published a consensus statement on the clinical criteria for consideration of biological treatment in CRSwNP ${ }^{(2,6)}$, which were further finetuned by the EPOS2020 expert panel ${ }^{(1)}$.

In order to understand the differences and similarities in efficacy of different biologicals, we provide an overview of reported study outcomes. For the sake of clarity, we focused on those outcome parameters that are mostly appreciated by the physicians, and divided them arbitrarily into patient relevant, i.e. of direct importance for the patient with impact on their quality of life (QoL), and patient irrelevant parameters, i.e. without direct impact on QoL.

We here provide a state-of-the art overview of the literature on biological treatments for CRSWNP including a comprehensive overview and comparison of inclusion criteria and outcome parameters. An attempt was made to show efficacy across different studies and with different molecules in CRSwNP patients using graphical overviews and meta-analysis.

\section{Materials and methods}

The overall objective of this manuscript is to allow an overview of published data on efficacy of biologicals in CRSwNP. We have selected 6 clinically relevant outcome parameters for analysis: nasal congestion and smell dysfunction scores, SNOT-22 scores, CT scan Lund-Mackay scores, smell test scores and nasal polyp score (NPS). The first 3 are considered patient relevant, and the latter 3 patient irrelevant outcome parameters. We analysed time-points between 16 to $25 \mathrm{w}$.

\section{Prisma search for inclusion of studies}

This study was performed and reported in accordance with the Preferred Reporting Items for Systematic Reviews and MetaAnalyses (PRISMA) recommended guidelines ${ }^{(7)}$. Randomized placebo controlled double blinded phase 2 and 3 trials on biologicals for CRSwNP patients published in peer-reviewed journals were included. Phase 1, open label, retrospective and prospective uncontrolled studies were excluded. The diagnosis of CRSwNP was based on the European Position Paper on rhinosinusitis and NPs (EPOS) (1). Trials on dupilumab, mepolizumab, omalizumab, reslizumab and benralizumab in CRSwNP are reported. In this review, an intervention with biologicals is defined as a treatment of at least two doses. We have chosen to analyse the outcome parameters in a timeframe of 16 to $25 \mathrm{w}$.

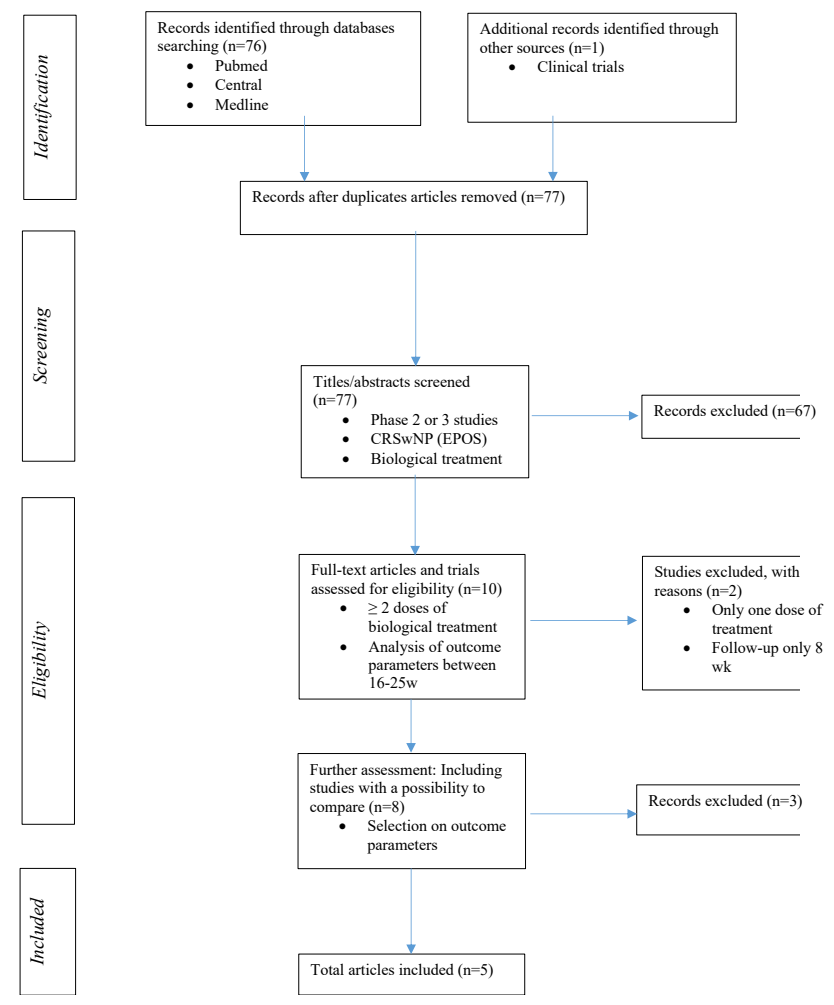

Figure 1. Prisma search for inclusion of studies.

A structured summary of the review process is depicted in Figure 1. We searched the following databases: MEDLINE (via PubMed), Cochrane Central Register of Controlled Trials (CENTRAL) and EMBASE. Search terms were adapted appropriately to suit each database structure. Beyond this first strategy, open search was performed resulting in 1 additional paper. The search was performed in September 2020 and we repeated end of October 2020 to check for additional recently published papers (that were not found). This resulted in a total of 77 articles. Full search terms can be found in the appendix.

An exploratory search for all applications of biologicals for CRSwNP was performed. Based on title and abstract screening, 67 out of the 77 articles were excluded because they did not fulfil the inclusion criteria set out for this search. For the remaining 10 articles full text was assessed for eligibility. This screening excluded 2 more studies. The first study had only one administration dose ${ }^{(8)}$. The second excluded study had a patient follow-up time of only 8 weeks ${ }^{(9)}$. Finally, we excluded 3 more studies as they were all based on a same phase 2a study, investigating additional parameters beyond the selection of outcome parameters we made in advance ${ }^{(10-12)}$, respectively investigating EQ-5D VAS and SF-36, type 2 pro-inflammatory biomarkers and LMK scoring. The paper of Bachert et al. (2016), based on the same phase 2a study, was retained in our search as it analyses parameters of our interest. 
Table 1. Biologicals in CRSwNP: overview of available studies and outcome parameters.

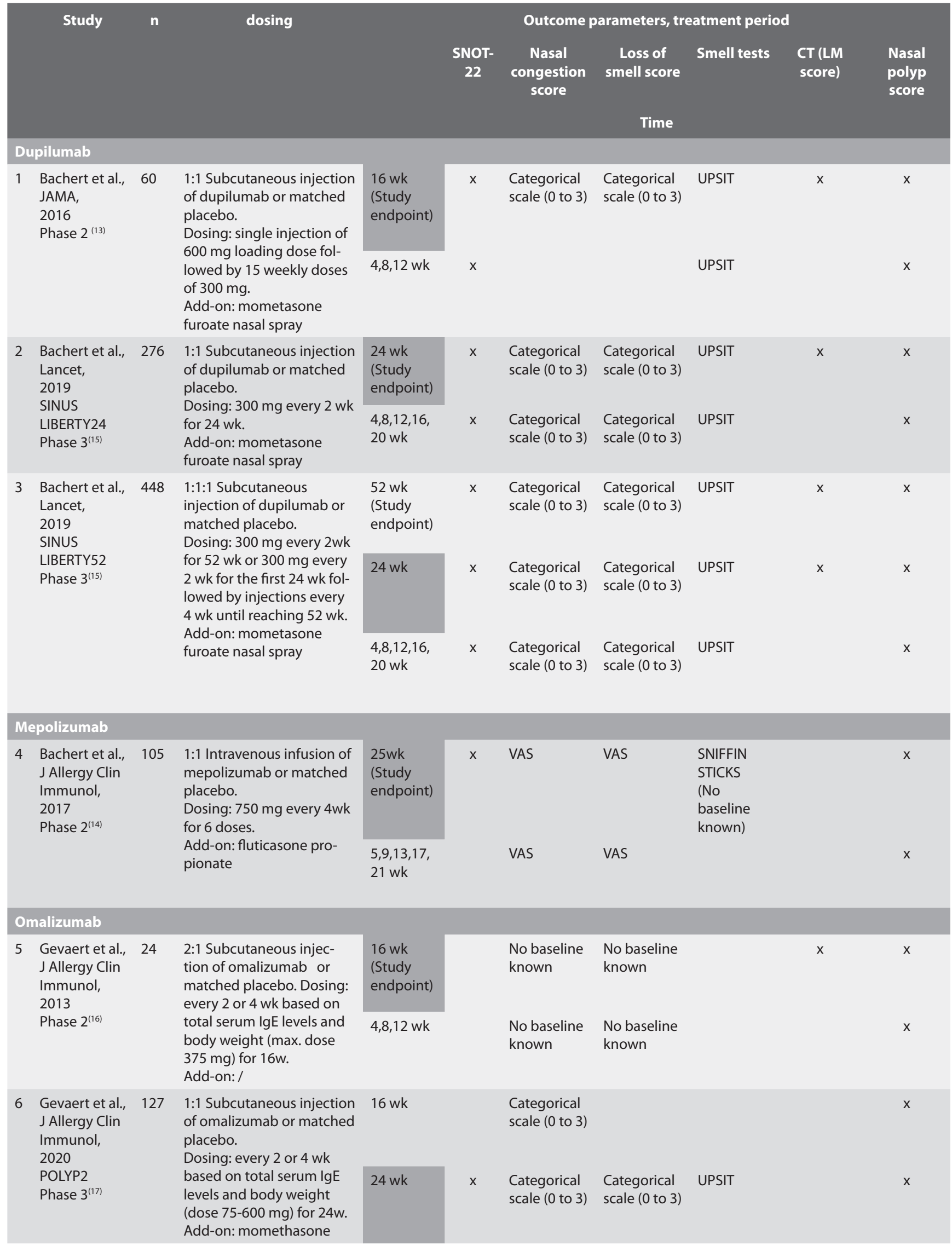




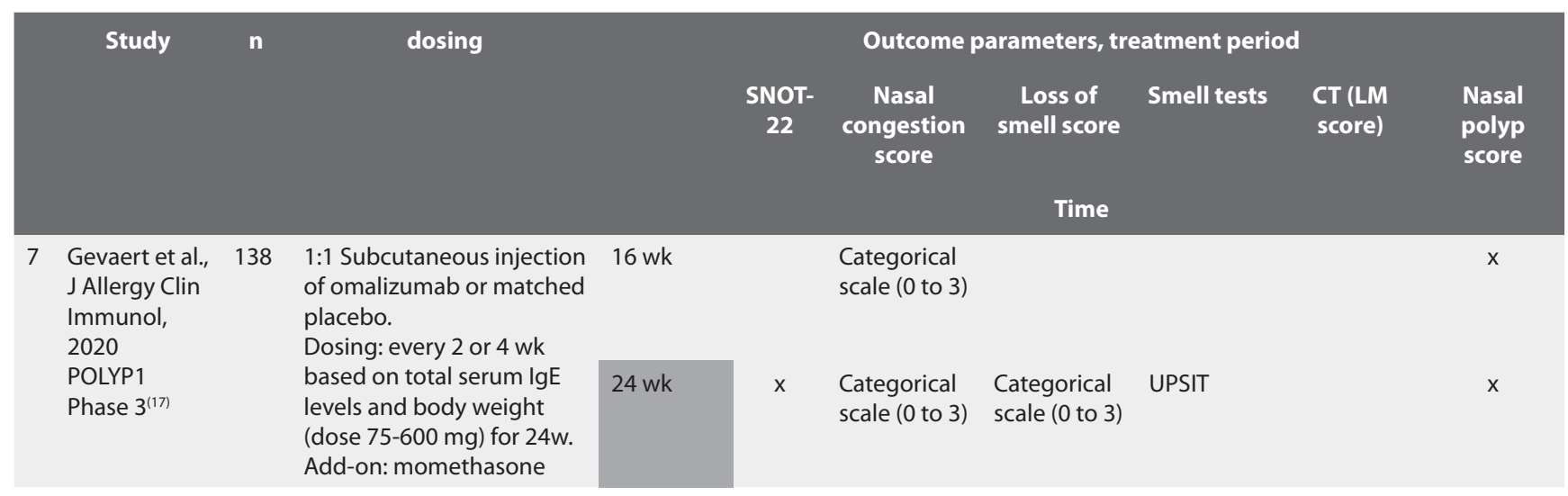

$\mathrm{X}$ : Data for this treatment period is given in the original study; -VAS: individual-symptom VAS scores (0-10), by asking patients to indicate the severity of their symptoms. - Categorical scale ( 0 to 3$)$ : symptoms were captured using a categorical scale $(0=$ no symptoms, $1=$ mild symptoms, $2=$ moderate symptoms, $3=$ severe symptoms). : Data for this treatment period is chosen for analysis.

The final result of this search retains 5 papers. As 2 papers each covered 2 different clinical trials, 7 distinct trials form the basis of our analysis ${ }^{(13-17)}$.

\section{Outcome parameters}

We evaluated change from baseline of the following 6 outcome parameters: 22-item SinoNasal Outcome Test (SNOT-22, score 0-110) scores ${ }^{(18)}$, nasal congestion scores (NCS), smell dysfunction scores (Loss of smell, LOS), smell test scores, Lund-Mackay CT score and nasal polyp score (NPS). Change from baseline was chosen to compensate for baseline differences.

Individual signs and symptoms, scored as LOS and NCS were captured daily by patients using a categorical scale from 0 to 3 ( $0=$ no symptoms, to $3=$ severe symptoms). In the mepolizumab study (14) a visual analogue scale (VAS) was used instead of scoring from 0-3 for these parameters. The smell tests were performed by University of Pennsylvania Smell Identification Test (UPSIT) in 6 out of the 7 studies and sniffin sticks in one ${ }^{(14)}$. UPSIT score ranges from 0 to 40 (higher scores of 35-40 indicate normal sense of smell and lower scores of 0-18 indicate anosmia) ${ }^{(19)}$. The Lund-Mackay CT score evaluates the patency of each sinus using a 0 to 2 scale ( $0=$ normal; $2=$ total opacification) and has a total score range from 0 to 24 (higher scores indicate more opacification) ${ }^{(20)}$. The NPS is graded based on polyp size (recorded as the sum of the right and left nostril scores with a range of $0-8$; higher scores indicate worse status) ${ }^{(16)}$. Data were obtained from tables and extracted from graphs of the original studies.

For each study, these 6 parameters were registered for baseline and treatment period. In Table 1, all available parameters at a particular period of follow-up are indicated with ' $X$ ' or with the name of the specific scoring system, whereas gaps in Table 1 represent missing data.

\section{Treatment period}

All included studies reported on a treatment period between 16 and 25 weeks. If more than one measurement was reported during the period of 16 to 25 weeks the measurement at the longest treatment moment was taken for analysis.

\section{Inclusion criteria for patients}

Table 2 shows a summary of the patient inclusion criteria used in the 7 studies. Age, use of intranasal corticosteroids, definition of NPS, presence of symptoms, earlier medical treatment or sinus surgery, comorbidity and serum total IgE at baseline are criteria defined in most studies.

EPOS2020 criteria for the use of biologicals met in the study population

Table 3 gives an overview of the appropriateness of the use of biologicals in the different study populations based on the criteria set out in EPOS2020 (1). Indications for biological treatment in CRSwNP are presence of bilateral polyps in a patient that had endoscopic sinus surgery (exceptional circumstances excluded) and who fulfills at least 3 of the 5 following criteria: evidence of type 2 inflammation (Tissue eos $\geq 10 / \mathrm{hpf}$, OR blood eos $\geq 250$, OR total $\lg E \geq 100$ ), need for systemic corticosteroids or contraindication to systemic steroids ( $\geq 2$ courses per $y r$, OR long term low dose (>3 months)), significantly impaired quality of life (SNOT$22 \geq 40$ ), significant loss of smell (anosmic on smell test (score depending on test)) and diagnoses of comorbid asthma (asthma needing regular inhaled corticosteroids). For each criterion, baseline clinical characteristics of the study population used in the 7 different studies are assessed against the cut-off points. Percentages of patients complying with these cut-off point are presented if given in tables, graphs or text of the original article. Figures at baseline are meanly mentioned as mean without an exact percentage given, making them unusable for this evalua- 
Table 2. Biologicals in CRSwNP: overview on available studies and inclusion criteria at baseline.

\begin{tabular}{|c|c|c|c|c|c|c|c|c|c|}
\hline \multirow{2}{*}{\multicolumn{2}{|c|}{ Study }} & $n$ & \multicolumn{7}{|c|}{ Inclusion criteria } \\
\hline & & & $\begin{array}{l}\text { Age } \\
(y r)\end{array}$ & $\begin{array}{l}\text { CRS symp- } \\
\text { toms de- } \\
\text { spite use of } \\
\text { intranasal } \\
\text { corticoster- } \\
\text { oids }\end{array}$ & NPS & $\begin{array}{l}\text { Presence of } \\
\text { symptoms }\end{array}$ & $\begin{array}{l}\text { Earlier medical } \\
\text { treatment or sinus } \\
\text { surgery }\end{array}$ & $\begin{array}{l}\text { Comorbid- } \\
\text { ity (NERD/ } \\
\text { bronchial } \\
\text { hyperactiv- } \\
\text { ity/ asthma) }\end{array}$ & $\begin{array}{c}\text { Serum } \\
\text { total lgE }\end{array}$ \\
\hline \multicolumn{10}{|c|}{ Dupilumab } \\
\hline 1 & $\begin{array}{l}\text { Bachert et al., } \\
\text { JAMA, } \\
2016 \\
\text { Phase } 2^{(13)}\end{array}$ & 60 & $18-65$ & $\begin{array}{l}\text { Use of INCS } \\
\text { for at least } 2 \\
\text { months }\end{array}$ & $\begin{array}{l}\text { Bilateral NPS } \geq 5 \\
\text { (maximum of } 8 \text { for } \\
\text { both nostrils), } \\
\text { with a score } \geq 2 \text { for } \\
\text { each nostril }\end{array}$ & $\begin{array}{l}\text { Presence of two or } \\
\text { more symptoms, one } \\
\text { of which should be } \\
\text { either nasal bloc- } \\
\text { kage / obstruction / } \\
\text { congestion or nasal } \\
\text { discharge (anterior / } \\
\text { posterior nasal drip) } \pm \\
\text { facial pain/pressure or } \\
\pm \text { reduction or loss of } \\
\text { smell }\end{array}$ & $\begin{array}{l}\text { Exclusion of patients } \\
\text { if nasal surgery within } \\
6 \text { months prior to } \\
\text { screening or if un- } \\
\text { dergone more than } \\
2 \text { surgeries for NP in } \\
\text { the past }\end{array}$ & $\begin{array}{l}50 \% \text { of pa- } \\
\text { tients with } \\
\text { comorbid } \\
\text { asthma }\end{array}$ & \\
\hline 2 & $\begin{array}{l}\text { Bachert et al., } \\
\text { Lancet, } \\
2019 \\
\text { SINUS } \\
\text { LIBERTY24 } \\
\text { Phase } 3^{(15)}\end{array}$ & 276 & $\geq 18$ & Use of INCS & $\begin{array}{l}\text { Bilateral NPS } \geq 5 \\
\text { (maximum of } 8 \text { for } \\
\text { both nostrils), } \\
\text { with a score } \geq 2 \text { for } \\
\text { each nostril }\end{array}$ & $\begin{array}{l}\text { Presence of two or } \\
\text { more symptoms, } \\
\text { nasal congestion or } \\
\text { obstruction and either } \\
\text { loss of smell or nasal } \\
\text { discharge }\end{array}$ & $\begin{array}{l}\text { Patients must have } \\
\text { received systemic } \\
\text { corticosteroids in the } \\
\text { preceding } 2 \mathrm{yr} \text { (if not } \\
\text { contraindicated) } \\
\text { or had previous sino- } \\
\text { nasal surgery }\end{array}$ & $\begin{array}{l}50 \% \text { of pa- } \\
\text { tients with } \\
\text { comorbid } \\
\text { asthma, } \\
\text { NERD or } \\
\text { both }\end{array}$ & \\
\hline 3 & $\begin{array}{l}\text { Bachert et al., } \\
\text { Lancet, } \\
2019 \\
\text { SINUS } \\
\text { LIBERTY52 } \\
\text { Phase } 3^{(15)}\end{array}$ & 448 & $\geq 18$ & Use of INCS & $\begin{array}{l}\text { Bilateral NPS } \geq 5 \\
\text { (maximum of } 8 \text { for } \\
\text { both nostrils), } \\
\text { with a score } \geq 2 \text { for } \\
\text { each nostril }\end{array}$ & $\begin{array}{l}\text { Presence of two or } \\
\text { more symptoms, } \\
\text { nasal congestion or } \\
\text { obstruction and either } \\
\text { loss of smell or nasal } \\
\text { discharge }\end{array}$ & $\begin{array}{l}\text { Patients must have } \\
\text { received systemic } \\
\text { corticosteroids in the } \\
\text { preceding } 2 \mathrm{yr} \text { (if not } \\
\text { contraindicated) } \\
\text { or had previous sino- } \\
\text { nasal surgery }\end{array}$ & $\begin{array}{l}50 \% \text { of pa- } \\
\text { tients with } \\
\text { comorbid } \\
\text { asthma, } \\
\text { NERD or } \\
\text { both }\end{array}$ & \\
\hline \multicolumn{10}{|c|}{ Mepolizumab } \\
\hline 4 & $\begin{array}{l}\text { Bachert et al., } \\
\text { J Allergy Clin } \\
\text { Immunol, } \\
2017 \\
\text { Phase } 2^{(14)}\end{array}$ & 105 & $18-70$ & $\begin{array}{l}\text { Use of INCS } \\
\text { for at least } 2 \\
\text { months }\end{array}$ & $\begin{array}{l}\text { Bilateral NPS } \geq 5 \\
\text { (maximum of } 8 \text { for } \\
\text { both nostrils), } \\
\text { with a score } \geq 2 \text { for } \\
\text { each nostril }\end{array}$ & $\begin{array}{l}\text { A visual analogue } \\
\text { scale(VAS) nasal symp- } \\
\text { tom score }>7\end{array}$ & $\begin{array}{l}\text { Patients received } \\
\text { intranasal steroids for } \\
\geq 3 \text { months and/or re- } \\
\text { ceived a short course } \\
\text { of oral steroids } \\
\text { and have undergone } \\
\text { at least } 1 \text { previous } \\
\text { nasal polyp removal } \\
\text { surgery }\end{array}$ & & \\
\hline \multicolumn{10}{|c|}{ Omalizumab } \\
\hline 5 & $\begin{array}{l}\text { Gevaert et al., } \\
\text { J Allergy Clin } \\
\text { Immunol, } \\
2013 \\
\text { Phase } 2^{(16)}\end{array}$ & 24 & $\geq 18$ & & $\begin{array}{l}\text { mucopurulent } \\
\text { discharge prima- } \\
\text { rily from middle } \\
\text { meatus and/or } \\
\text { oedema/muco- } \\
\text { sal obstruction } \\
\text { primarily in middle } \\
\text { meatus, and/or CT } \\
\text { changes showing } \\
\text { mucosal changes } \\
\text { within the ostio- } \\
\text { meatal complex } \\
\text { and/or sinuses }\end{array}$ & $\begin{array}{l}\text { Presence of two or } \\
\text { more symptoms, one } \\
\text { of which should be } \\
\text { either nasal bloc- } \\
\text { kage / obstruction / } \\
\text { congestion or nasal } \\
\text { discharge (anterior / } \\
\text { posterior nasal drip) } \pm \\
\text { facial pain/pressure or } \\
\pm \text { reduction or loss of } \\
\text { smell }\end{array}$ & & $\begin{array}{l}\text { Comorbid } \\
\text { asthma for } \\
\text { more than } \\
2 \mathrm{yr}\end{array}$ & $\begin{array}{l}30-700 \\
\mathrm{IU} / \mathrm{ml}\end{array}$ \\
\hline 6 & $\begin{array}{l}\text { Gevaert et al., } \\
\text { J Allergy Clin } \\
\text { Immunol, } \\
2020 \text { POLYP2 } \\
\text { Phase } 3 \\
\text { (17) }\end{array}$ & 127 & $18-75$ & $\begin{array}{l}\text { Use of INCS } \\
\text { for at least } 1 \\
\text { month }\end{array}$ & $\begin{array}{l}\text { Bilateral NPS } \geq 5 \\
\text { (maximum of } 8 \text { for } \\
\text { both nostrils), } \\
\text { with a score } \geq 2 \text { for } \\
\text { each nostril }\end{array}$ & $\begin{array}{l}\mathrm{NCS} \geq 2 \\
\text { SNOT-22 score } \geq 20 \\
\text { Impaired health- } \\
\text { related QOL }\end{array}$ & & & $\begin{array}{l}30-1500 \\
\mathrm{IU} / \mathrm{ml}\end{array}$ \\
\hline
\end{tabular}




\begin{tabular}{|c|c|c|c|c|c|c|c|c|c|}
\hline & \multirow[t]{2}{*}{ Study } & \multirow[t]{2}{*}{$\mathbf{n}$} & \multicolumn{7}{|c|}{ Inclusion criteria } \\
\hline & & & $\begin{array}{l}\text { Age } \\
\text { (yr) }\end{array}$ & $\begin{array}{l}\text { CRS symp- } \\
\text { toms de- } \\
\text { spite use of } \\
\text { intranasal } \\
\text { corticoster- } \\
\text { oids }\end{array}$ & NPS & $\begin{array}{l}\text { Presence of } \\
\text { symptoms }\end{array}$ & $\begin{array}{c}\text { Earlier medical } \\
\text { treatment or sinus } \\
\text { surgery }\end{array}$ & $\begin{array}{l}\text { Comorbid- } \\
\text { ity (NERD/ } \\
\text { bronchial } \\
\text { hyperactiv- } \\
\text { ity/ asthma) }\end{array}$ & $\begin{array}{l}\text { Serum } \\
\text { total lgE }\end{array}$ \\
\hline 7 & $\begin{array}{l}\text { Gevaert et al., } \\
\text { J Allergy Clin } \\
\text { Immunol, } \\
2020 \text { POLYP1 } \\
\text { Phase } 3 \\
\text { (17) }\end{array}$ & 138 & $18-75$ & $\begin{array}{l}\text { Use of INCS } \\
\text { for at least } 1 \\
\text { month }\end{array}$ & $\begin{array}{l}\text { Bilateral NPS } \geq 5 \\
\text { (maximum of } 8 \text { for } \\
\text { both nostrils), } \\
\text { with a score } \geq 2 \text { for } \\
\text { each nostril }\end{array}$ & $\begin{array}{l}\text { NCS } \geq 2 \\
\text { SNOT- } 22 \text { score } \geq 20 \\
\text { Impaired health- } \\
\text { related QOL }\end{array}$ & & & $\begin{array}{l}30-1500 \\
\mathrm{IU} / \mathrm{ml}\end{array}$ \\
\hline
\end{tabular}

tion. Blank fields in the table correspond to missing or unusable data.

\section{Used data and statistical analysis}

Data were obtained from the 7 original studies using tables, text of the paper and published supplementary material. Data that could not be obtained otherwise were measured in the figures. In SINUS LIBERTY $52^{\left({ }^{(15)}\right.}$ a pooled analysis was performed. For this particular study the table showed data for follow-up at 24 weeks in a pooled group of patients. This pooled treatment group include group $A(n=150)$ and group $B(n=145)$ treated with another dosing scheme. The mean change from baseline was calculated using the baseline data of group $A$ and B. If absolute values at time of follow-up were missing, data were calculated out of least square mean change from baseline ${ }^{(17)}$ and ${ }^{(14)}$ (for NPS). When AM and PM data were given, AM data were used.

Standard deviation (s.d.) was given, if reported in the original study. If s.d. was not directly given, s.d. was calculated from standard error of the mean (sem), interquartile range or confidence intervals. If no values for variance were given, values were measured in figures. If s.d. of the treatment outcome could not be found any other way, the s.d. of the baseline value was taken (21).

Statistical analyses were performed using RevMan 5.3 software. Meta-analysis was performed for SNOT-22 and mean change from baseline of the nasal polyp score (NPS) in line with recommendations from the Cochrane Collaboration and the Quality of Reporting of Meta-analyses (QUORUM) guidelines ${ }^{(22)}$. For the other variables data were incomplete. Variables were analysed using mean differences (MD) for SNOT-22 and standardised mean differences (SMD) for NPS ${ }^{(23)}$ with $95 \%$ confidence intervals (Cls). The results were pooled using either a fixed effect or random effect model as appropriate ${ }^{(23)}$. Heterogeneity of the exposure effects was evaluated statistically using the 12 statistic to quantify heterogeneity across studies ${ }^{(24)}$. A I 2 value of $>50 \%$ was taken as evidence of substantial heterogeneity and in such cases a random effect model was used. A chi-squared test for hetero- geneity was also performed and the ' $p$ ' values are presented.

\section{Results}

The search resulted in 7 studies, published in 5 papers ${ }^{(13-17)}$ that were included in this article. Table 1 shows a summary of these studies, including number of participants (n), dosing scheme and the outcome parameters available for the different treatment follow-up periods in time.

\section{Inclusion criteria for patients}

Inclusion criteria for the 7 studies are given in Table 2 . We tried to evaluate whether the included patients fulfilled the EUFOREA/EPOS2020 criteria for treatment with biologicals. Not all relevant data were given and because in the EUFOREA/ EPOS2020 criteria 3 out of 5 criteria are needed (in patients that had surgery before) it was not possible to deduct what percentage of the patients fulfilled the EUFOREA/EPOS2020 criteria, see Table 3.

All studies evaluated adult patients ( $>18$ ) with CRSwNP having symptoms despite use of at least 1-2 months of intranasal corticosteroids, although in the study of Gevaert et al., $2013^{(16)}$ not explicitly mentioned. All but one study included patients with a bilateral endoscopic nasal polyp score of at least 5 (maximum score of 8). In the study of Gevaert et al., $2013^{(16)}$ nasal polyposis is not clearly defined with cut-off points. In 4 studies ${ }^{(13,15,16)}$, of which one article ${ }^{(15)}$ contains 2 studies, patients were expected to have at least 2 of the following symptoms prior to screening: nasal obstruction or nasal discharge and/or facial pain or pressure and a reduction/loss of smell ${ }^{(1)}$. The criteria for earlier sinus surgery and/or courses of systemic corticosteroids varied significantly in the various studies. Apart from the study from Gevaert et al., $2013^{(16)}$ where patients received omalizumab because of their comorbid asthma (present for more than 2 years), asthma was not an inclusion criterium. As expected, when indicated, more than $50 \%$ of patients were having asthma in all 7 study populations. Percentage of patients with blood eosinophilia was not mentioned in the original papers. 
Table 3. Indications for biological treatment in CRSWNP (EPOS2020) met in the different studies.

\begin{tabular}{|c|c|c|c|c|c|c|c|}
\hline \multicolumn{3}{|c|}{$\begin{array}{l}\text { Criteria } \\
\text { ( } \geq 3 \text { are required) }\end{array}$} & $\begin{array}{l}\text { Evidence of type } 2 \\
\text { inflammation }\end{array}$ & $\begin{array}{l}\text { Need for systemic } \\
\text { corticosteroids or } \\
\text { contraindication to } \\
\text { systemic steroids }\end{array}$ & $\begin{array}{l}\text { Significantly } \\
\text { impaired quality } \\
\text { of life }\end{array}$ & $\begin{array}{l}\text { Significant loss of } \\
\text { smell }\end{array}$ & $\begin{array}{l}\text { Diagnosis of } \\
\text { comorbid asthma }\end{array}$ \\
\hline \multicolumn{3}{|c|}{$\begin{array}{l}\text { Cut-off points } \\
\text { (at baseline) }\end{array}$} & $\begin{array}{l}\text { Tissue eos } \geq 10 / \mathrm{hpf} \\
\text { OR blood eos } \geq 250 \text {, } \\
\text { OR total serum IgE } \\
\geq 100\end{array}$ & $\begin{array}{l}\geq 2 \text { courses per yr, } \\
\text { OR long term ( }>3 \\
\text { months) low dose } \\
\text { steroids }\end{array}$ & SNOT-22 $\geq 40$ & $\begin{array}{l}\text { Anosmic on smell } \\
\text { test } \\
\text { (score depending on } \\
\text { test) } \\
\text { f. ex. UPSIT < } 19= \\
\text { anosmia }\end{array}$ & $\begin{array}{l}\text { Asthma needing } \\
\text { regular inhaled } \\
\text { corticosteroids }\end{array}$ \\
\hline & Study & $\mathbf{n}$ & & & & & \\
\hline \multicolumn{8}{|c|}{ Dupilumab } \\
\hline 1 & $\begin{array}{l}\text { Bachert et al., } \\
\text { JAMA, } \\
2016 \\
\text { Phase } 2^{(13)}\end{array}$ & 60 & & & & & $\begin{array}{l}58 \% \text { of patients with } \\
\text { comorbid asthma }\end{array}$ \\
\hline 2 & $\begin{array}{l}\text { Bachert et al., } \\
\text { Lancet, } \\
2019 \\
\text { SINUS } \\
\text { LIBERTY24 } \\
\text { Phase } 3^{(15)}\end{array}$ & 276 & & $\begin{array}{l}64 \% \text { of patients } \\
\text { received systemic } \\
\text { corticosteroid in the } \\
\text { preceding } 2 \mathrm{yr}\end{array}$ & & $\begin{array}{l}76 \% \text { of patients had } \\
\text { anosmia }\end{array}$ & $\begin{array}{l}58 \% \text { of patients with } \\
\text { comorbid asthma }\end{array}$ \\
\hline 3 & $\begin{array}{l}\text { Bachert et al., } \\
\text { Lancet, } \\
2019 \\
\text { SINUS } \\
\text { LIBERTY52 } \\
\text { Phase } 3^{(15)}\end{array}$ & 448 & & $\begin{array}{l}80 \% \text { of patients } \\
\text { received systemic } \\
\text { corticosteroid in the } \\
\text { preceding } 2 \mathrm{yr}\end{array}$ & & $\begin{array}{l}76 \% \text { of patients had } \\
\text { anosmia }\end{array}$ & $\begin{array}{l}60 \% \text { of patients with } \\
\text { comorbid asthma }\end{array}$ \\
\hline \multicolumn{8}{|c|}{ Mepolizumab } \\
\hline 4 & $\begin{array}{l}\text { Bachert et al., } \\
\text { J Allergy Clin } \\
\text { Immunol, } \\
2017 \\
\text { Phase } 2{ }^{(14)}\end{array}$ & 105 & & & & & $\begin{array}{l}78 \% \text { of patients with } \\
\text { comorbid asthma } \\
\text { (mild or moderate } \\
\text { disease) }\end{array}$ \\
\hline \multicolumn{8}{|c|}{ Omalizumab } \\
\hline 5 & $\begin{array}{l}\text { Gevaert et al., } \\
\text { J Allergy Clin } \\
\text { Immunol, } \\
2013 \\
\text { Phase } 2^{(16)}\end{array}$ & 24 & & & & & $\begin{array}{l}\text { 100\% of patients with } \\
\text { comorbid asthma } \\
\text { (based on global } \\
\text { initiative for Asthma } \\
\text { guidelines }\end{array}$ \\
\hline 6 & $\begin{array}{l}\text { Gevaert et al., } \\
\text { J Allergy Clin } \\
\text { Immunol, } \\
2020 \text { POLYP2 } \\
\text { Phase } 3 \\
\text { (17) }\end{array}$ & 127 & & $\begin{array}{l}44 \% \text { of patients } \\
\text { received } \geq 2 \text { courses } \\
\text { systemic corticoste- } \\
\text { roid in the preceding } \\
\text { yr }\end{array}$ & & $\begin{array}{l}81,5 \% \text { of patients had } \\
\text { anosmia }\end{array}$ & $\begin{array}{l}61 \% \text { of patients with } \\
\text { comorbid asthma }\end{array}$ \\
\hline 7 & $\begin{array}{l}\text { Gevaert et al., } \\
\text { J Allergy Clin } \\
\text { Immunol, } \\
2020 \text { POLYP1 } \\
\text { Phase } 3 \\
\text { (17) }\end{array}$ & 138 & & $\begin{array}{l}32 \% \text { of patients } \\
\text { received } \geq 2 \text { courses } \\
\text { systemic corticoste- } \\
\text { roid in the preceding } \\
\text { yr }\end{array}$ & & $\begin{array}{l}81,5 \% \text { of patients had } \\
\text { anosmia }\end{array}$ & $\begin{array}{l}53 \% \text { of patients with } \\
\text { comorbid asthma }\end{array}$ \\
\hline
\end{tabular}

\section{Outcomes evaluated}

We evaluated the following 6 outcome parameters: 22 -item SinoNasal Outcome Test (SNOT-22, score 0-110) scores, nasal congestion scores (NCS), smell dysfunction scores (Loss of smell, LOS), smell test scores, Lund-Mackay CT score and nasal polyp score (NPS). Table 4 shows baseline, data after treatment and changes from baseline to treatment follow-up for all parameters. A significant improvement over placebo of the different outcome parameters was observed for all 3 biologicals. 


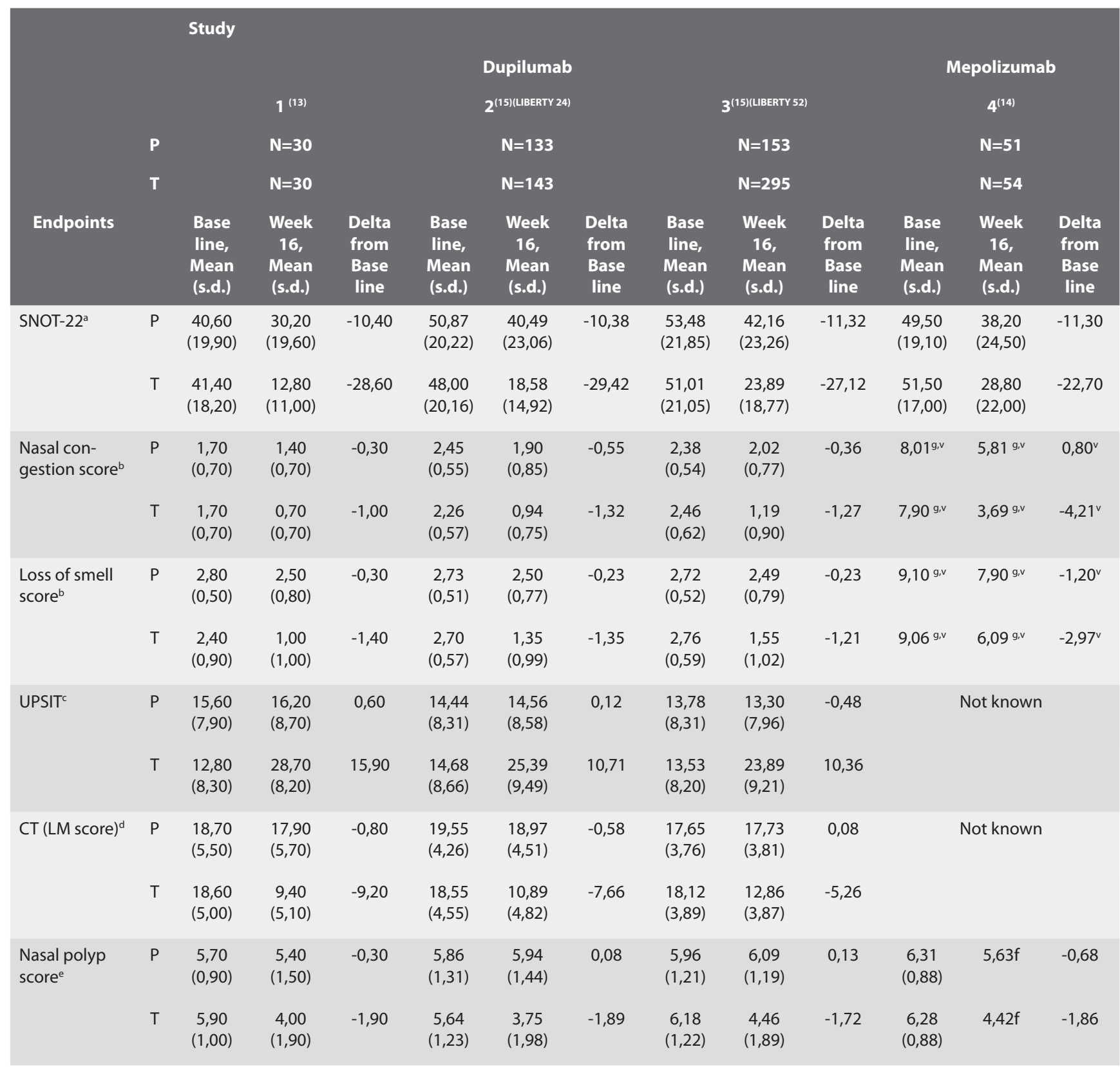

P, placebo; T, treatment (dupilumab, mepolizumab, omalizumab); N, number of patients in group. ${ }^{\text {a }}$ Range of 0 to 110 (higher scores indicate poorer outcomes) and a minimally clinically important difference of 8,$90 ;{ }^{b}$ Symptoms were captured using a catergorical scale $(0=$ no symptoms, $1=$ mild symptoms, 2 = moderate symptoms, 3 = severe symptoms), v or by using VAS scores (0-10), by asking patients to indicate the severity of their symptoms; ${ }^{\mathrm{c}}$ Range of 0 to 40 (higher scores of 35-40 inidicate normal sense of smell); ${ }^{\mathrm{d}}$ Range of 0 to 24 (higher scores indicate more opacification); ${ }^{\mathrm{e}}$ Range of 0 to 8 (higher scores indicate worse outcomes); ${ }^{f}$ Data calculated out of LS mean change from baseline, therefore s.d. not known; ${ }^{g} \mathrm{~s} . \mathrm{d}$. calculated out of $\mathrm{Cl}$; ${ }^{\mathrm{h}}$ Data derived from the text without mentioning s.d., therefore s.d. not known

\section{SNOT-22}

Baseline SNOT-22 score were between 40 and 53 for the studies on dupilumab and mepolizumab and around 60 for Omalizumab (Figure 2). The placebo effect was around 10 points in most studies. The mean difference of treatment versus placebo for the combined treatment effect was 18.0 [95\% Cl -20.3 - -15.6] with $-19.6[95 \% \mathrm{Cl}-22.5--16.7]$ for dupilumab, $-9.4[95 \% \mathrm{Cl}$ $-18.3--0.5]$ for mepolizumab and $-16.3[95 \% \mathrm{Cl}-20.7--15.6]$ for omalizumab (Figure 8). These differences did not reach significance $(p=0.07)$. 
Table 4. Change from baseline to treatment follow-up in patients with CRSwNP treated with placebo or biological (dupilumab, mepolizumab, omalizumab) (continued).

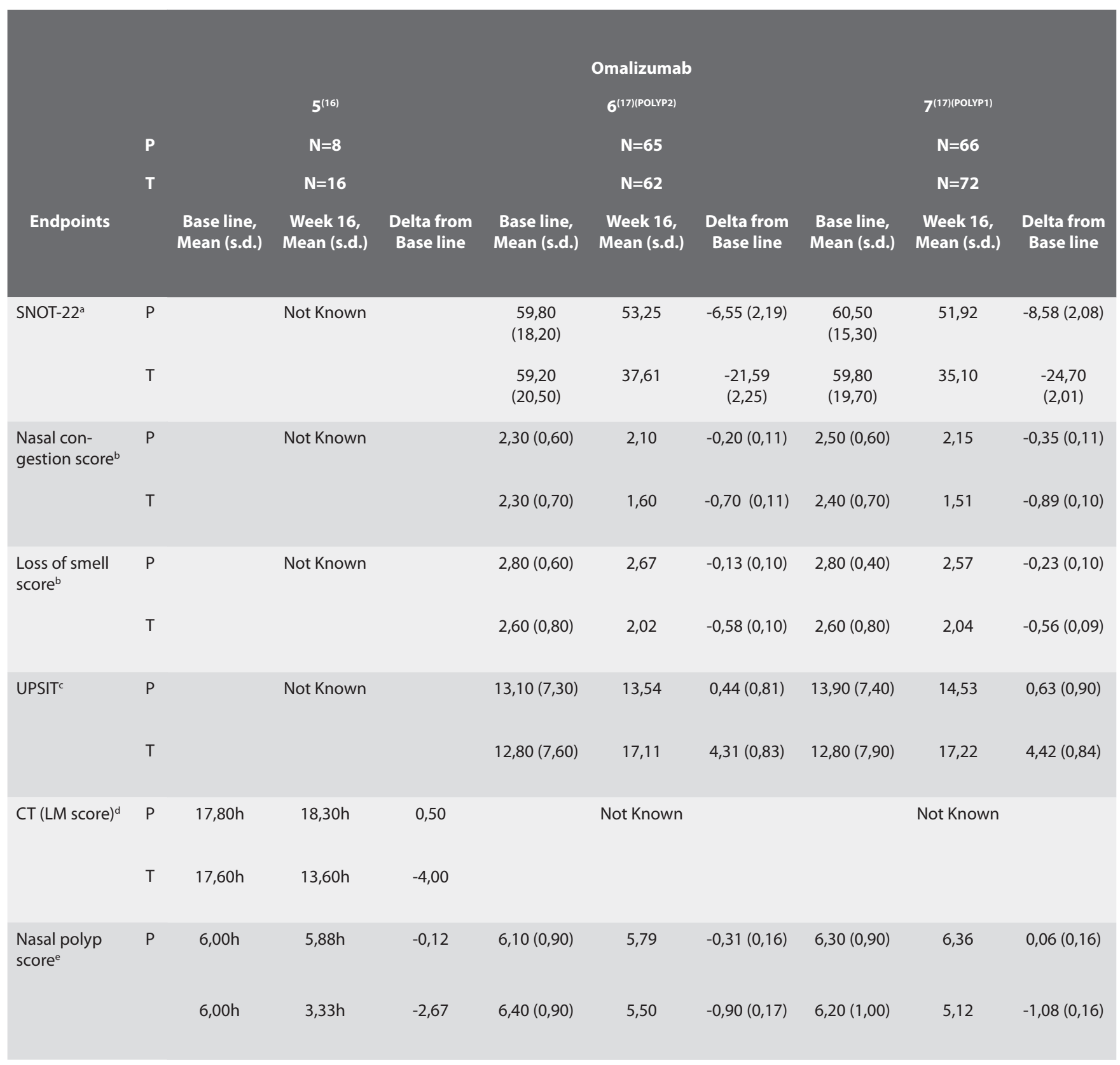

\section{Nasal congestion scores (NCS)}

The nasal congestion score was a little bit over 2 (2.3-2.5) for most studies apart from the first dupilumab study (1.7) (Figure $3)^{(13)}$. In the mepolizumab study ${ }^{(14)}$ NCS was measured with VAS which is probably not totally comparable. The difference of treatment versus placebo was around 1 for all treatments.

\section{Loss of smell score (LOS)}

Baseline loss of smell score was very comparable in the different studies (2.4-2.8) (Figure 4). In the mepolizumab study ${ }^{(14)}$ LOS was measured with VAS which is probably not totally compara- ble. The difference of treatment versus placebo was remarkable especially for dupilumab.

\section{Smell testing}

Six studies used the UPSIT score. Baseline UPSIT was very comparable in the different studies (12.8-15.6) (Figure 5). The difference of treatment versus placebo was remarkable especially for dupilumab (around 10 points). The study using sniffin sticks (14) did not report baseline data and therefore could not be included in the analysis. 


\section{SNOT-22 (score from 0 to 110)}

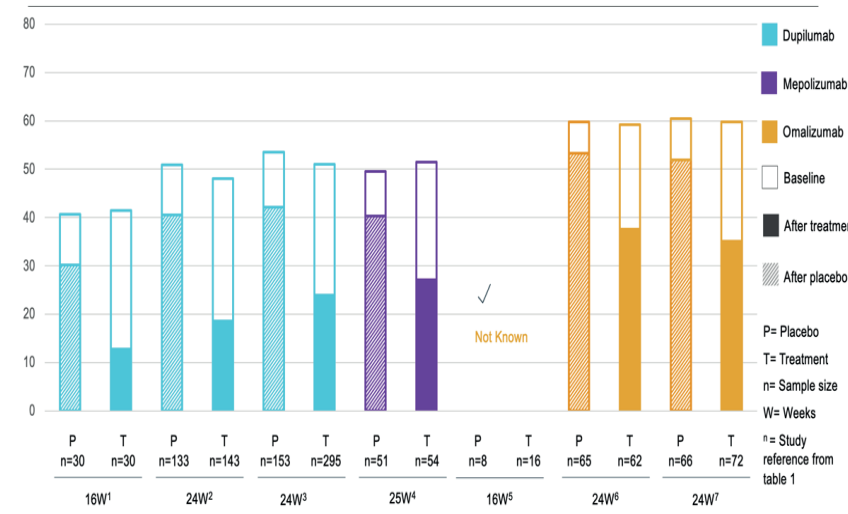

Figure 2. SNOT-22.

\section{Nasal congestion score (NCS)}

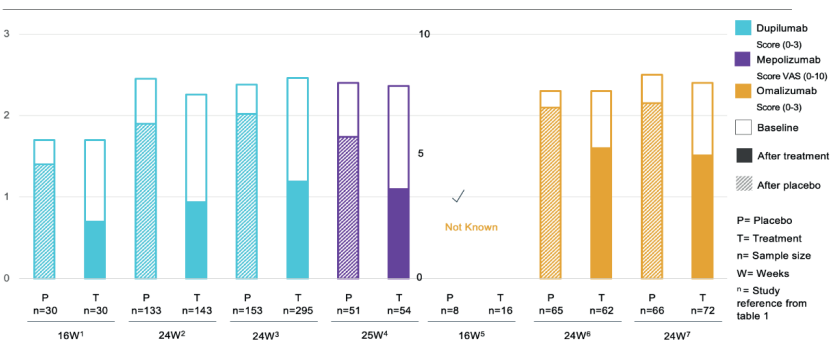

Figure 3 Nasal congestion score.

\section{Loss of smell (LOS)}

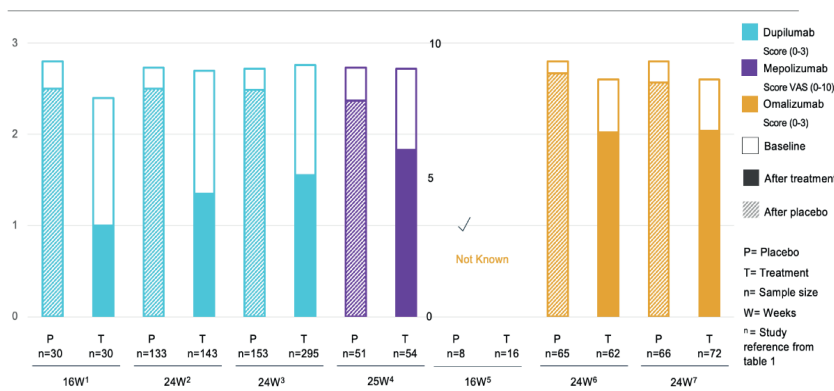

Figure 4. Loss of smell.

\section{CT scan and NPS}

Baseline scores were high for CT scan (17.6- 19.5) and NPS (5.66.4) in all studies where data were available (Figures 6 and 7). Standard mean difference of NPS was - 0.85 [95\% Cl - 1.06- -0.64], with no significant differences between the studies (Figure 9).

\section{Discussion}

In the past year, treatment with biologicals has become available for patients with CRSwNP in certain countries. At this moment dupilumab and omalizumab are available and others are expected to follow soon. EUFOREA and EPOS2020 working

\section{UPSIT (score from 0 to 40)}

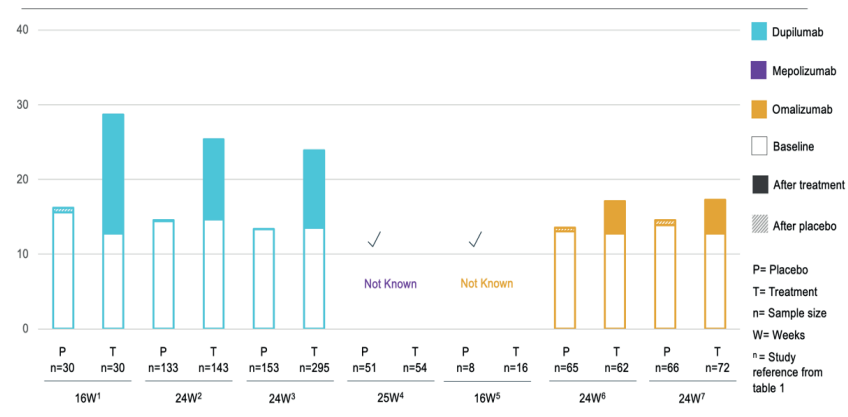

Figure 5. Smell test.

\section{CT scan (LM score) (score from 0 to 24)}

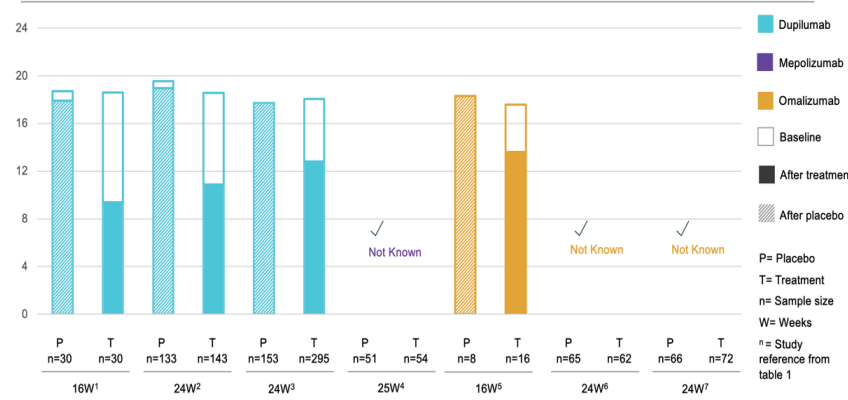

Figure 6. CT scan (LM-score).

\section{Nasal polyp score (NPS) (score from o to 8)}

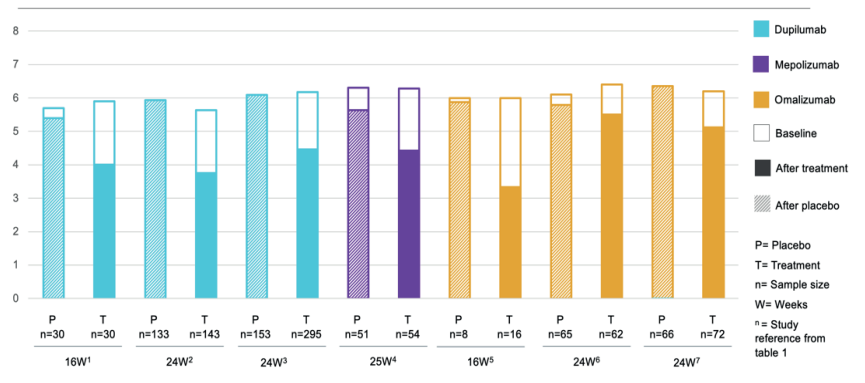

Figure 7. Nasal polyp score. endotype 2 disease that failed appropriate treatment including FESS and corticosteroid treatment ${ }^{(1,2)}$. As head to head comparisons of biologicals in CRSwNP are lacking, this analysis tries to shed some light on the similarities and differences of the available biologicals for severe CRSwNP patients.

Published studies until present do not show significant differences between the biologicals, despite the lack of homogeneity across study reports. Comparison of different trials is always inferior to a head-to-head comparison and we do realize that trials, especially the mepolizumab trial ${ }^{(14)}$ and the first omali- 


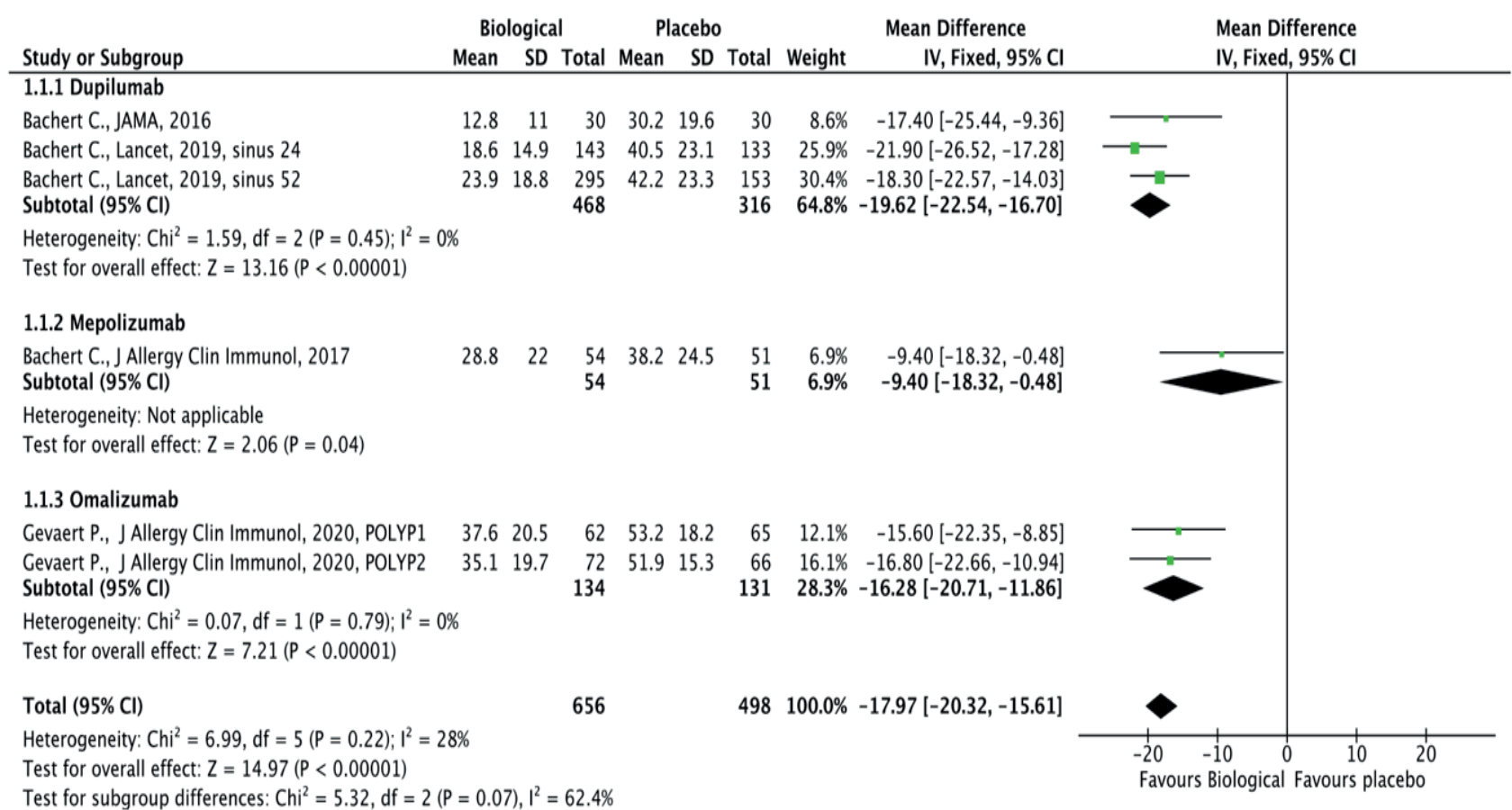

Figure 8. Forest plot of the effect of biological vs placebo for SNOT-22 at completion of intervention (16-25 weeks) in patients with CRSwNP.

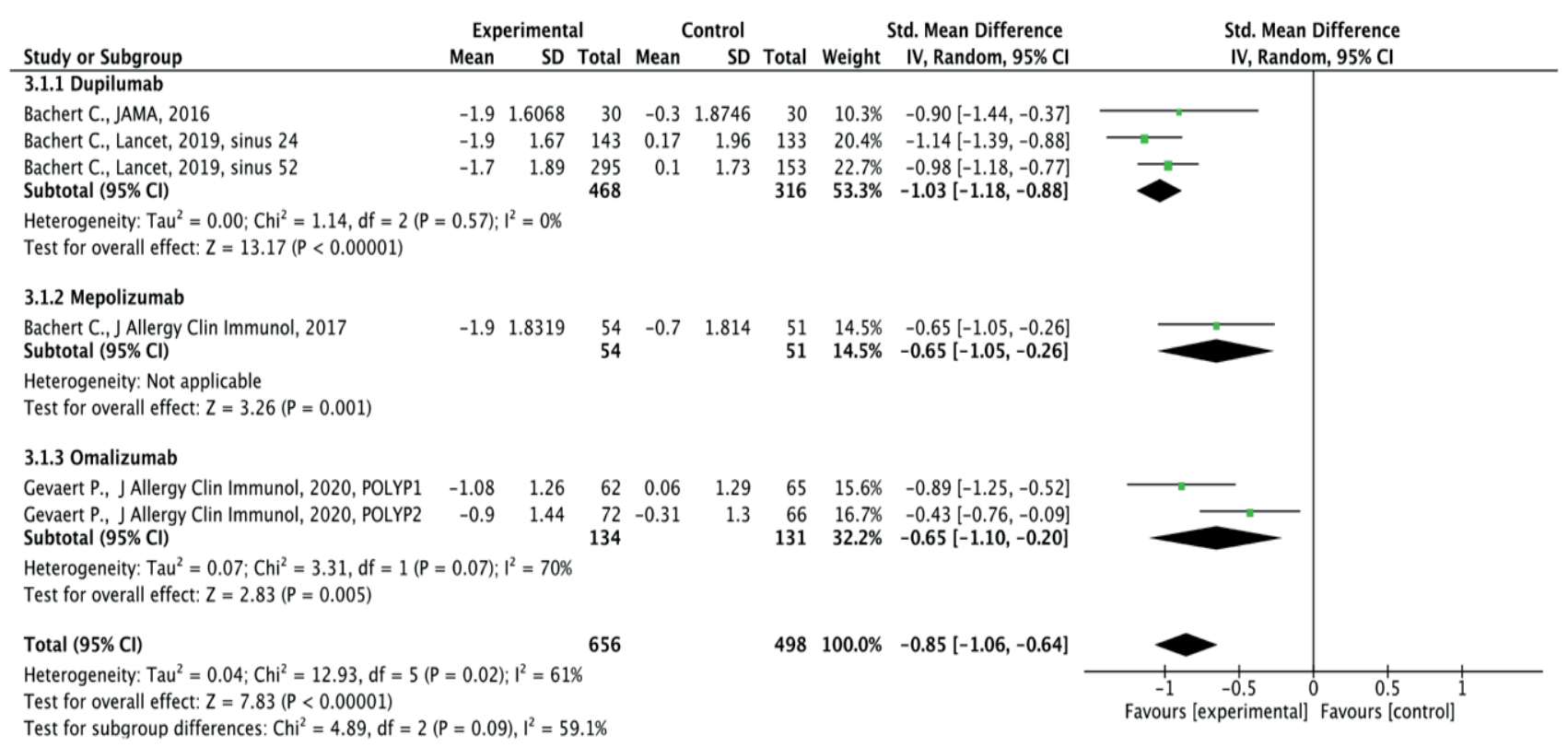

Figure 9. Forest plot of the effect of biological vs placebo on standard mean difference of the nasal polyp score at completion of intervention (16-25 weeks) in patients with CRSwNP.

zumab trial ${ }^{(16)}$ have designs and inclusion criteria that are not fully comparable. However, we felt that the importance of this overview was of enough scientific and clinical value to publish and bring to the attention of the Rhinology community. Apart from the difficulties mentioned above, we needed to make a number of choices to have the best comparison possible. A first issue was the difference in treatment period. We wanted the treatment period to be relevant for the chronic condition CRSWNP and as comparable as possible across study reports. It appeared that all studies had a time point of analysis between 16 and 25 weeks. Within this range, the latest available time point was chosen for each study. Because most studies provided data during that time period we could ascertain that in most studies the impact of the treatment started to reach a 
plateau after 14 weeks and with limited differences between 16 and 25 weeks of treatment. For dupilumab, differences in SNOT-22 scores between 16 and 25 weeks were less than $5 \%$ (Bachert et al., 2019, Figure S3-C ${ }^{(15)}$ ). For future studies, analyses of more time-points might be performed allowing evaluation of duration of treatment for reaching specific efficiency levels. A further limitation was that not all data were reported in the same way. Especially, symptoms were reported as symptom scores (0 to 3$)^{(13,15,16,17)}$ and as VAS ${ }^{(14)}$. One could argue that these two ways of measuring symptoms are too different to be compared reliably, but we felt that presenting them in a comprehensive way would allow the interpreter to have an idea of effect size and comparability. Also for smell evaluation, different means of smell tests are being used, i.e. UPSIT and Sniffing Sticks. Both data have been included in this report for the sake of completeness.

A further weakness was the missing data in some studies. We chose to report on change from baseline to allow for baseline differences. However, some studies ${ }^{(14,16)}$ did not report baseline values for some parameters and for that reason could not be included. Also, we are aware of some large studies being performed and/or analysed at the moment that are not yet published and could not be included in this study.

Despite these limitations, one can observe consistent efficacy across the studies involving 3 different biological molecules, which underscores the good news of a new therapeutic era in CRSwNP care with a non-surgical option besides (oral) corticosteroids and antibiotics. Effect sizes of dupilumab, mepolizumab and omalizumab seem large enough to reflect the major and relevant reduction in symptom burden as experienced by patients. Of note, the effect sizes of dupilumab on objective and subjective parameters of smell loss are impressive and reflect the clinical experience of major reduction of smell impairment in treated patients. An important aspect of interpretation of the biological data in CRSwNP is that patients receiving the placebo injections are not receiving only placebo but treatment as an addition to standard of care, i.e. nasal corticosteroids and saline douching.

\section{Conclusion}

This study is a careful attempt to compare different biologicals in the treatment of CRSwNP. Many questions remain to be answered. Until now we are not aware of any studies evaluating differences in response to biologicals in patients with different CRSwNP endotypes as has been reported in asthma. In asthma, an indirect treatment comparison of 3 different IL-5 pathway directed therapies in 11 study reports have been conducted showing that mepolizumab was associated with significantly greater improvements in clinically significant exacerbations and asthma control than reslizumab and benralizumab ${ }^{(25)}$. Given the shortcomings of direct comparisons, the conclusions have been subject to ongoing discussions on methodological issues ${ }^{(26)}$. A comparable study to ours in asthma ${ }^{(27)}$ has recently been performed, with some interesting observations in differences in efficacy. Here again, conclusions of such comparison need to be interpreted with caution as populations selected for analyses differed at the level of eosinophil counts and oral corticosteroid use, as highlighted by dr Neil Martin, ${ }^{(28)}$. Therefore, and given the low number of studies in CRSWNP, we cannot make strong conclusions on differences in efficacy levels between the 3 reported molecules for CRSwNP treatment. Moreover, it would be very interesting to see what percentage of the patients in these studies fulfilled the EUFOREA/EPOS2020 criteria and whether patients fulfilling these criteria did better than the ones who did not. This was not yet assessable. Real-life registries, comparative trials and/or endotype-driven treatment plans will all provide the answers to the multiple questions that are still open today, like responder rates of CRSWNP patients treated with biologicals, optimal duration of treatment with/without recurrence of disease after stopping the treatment, treatment of biologicals in relation to sinus surgery for CRSWNP, and optimal timing of biological treatment in the disease process taking into account preventive and curative considerations. Ongoing studies will undoubtedly lead to a better view on what biological is best for what particular subtype of CRSwNP.

\section{Authorship contribution}

PWH, WJF and EV designed the study. EV conducted the study and analyzed the data. The meta-analysis was done by WJF. PWH and EV wrote the manuscript.

\section{Conflict of interest}

EV has no conflict of interest in relation to this study and the results described in the manuscript. Both PWH and WJF have been consultant and lecturer for Sanofi/Regeneron, Novartis and/or Astra-Zeneca.

\section{Financial disclosure}

No funding has been received to support the development of this article.

\section{References}

1. Fokkens WJ, Lund VJ, Hopkins C, Hellings PW, Kern R, Reitsma S, et al. European Position Paper on Rhinosinusitis and Nasal Polyps 2020. Rhinology. 2020;58(Supp

\section{S29):1-464.}

2. Fokkens WJ, Lund V, Bachert C, Mullol J, Bjermer L, Bousquet J, et al. EUFOREA consensus on biologics for CRSWNP with or without asthma. Allergy. 2019;74(12):2312-9.
3. De Greve G, Hellings PW, Fokkens WJ, Pugin B, Steelant B, Seys SF. Endotype-driven treatment in chronic upper airway diseases. Clin Transl Allergy. 2017;7:22

4. van der Veen J, Seys SF, Timmermans M 
Levie P, Jorissen M, Fokkens WJ, et al. Reallife study showing uncontrolled rhinosinusitis after sinus surgery in a tertiary referral centre. Allergy. 2017;72(2):282-90.

5. Prokopakis E, Vardouniotis A, Bachert C, Bousquet J, Carrie S, Castelnuevo P, et al. Rhinology Future Debates 2018, a EUFOREA Report. Rhinology. 2020;58(4):384-393.

6. Pugin B, Deneyer L, Bachert C, Alobid I, Bousquet J, De Carlo G, et al. Patient Advisory Board for Chronic Rhinosinusitis - A EUFOREA initiative. Rhinology. 2019;57(5):331-5.

7. Moher D, Liberati A, Tetzlaff J, Altman DG Group P. Preferred reporting items for systematic reviews and meta-analyses: the PRISMA statement. Int J Surg. 2010;8(5):33641.

8. Gevaert P, Lang-Loidolt D, Lackner A, Stammberger $H$, Staudinger $H$, Van Zele $\mathrm{T}$, et al. Nasal IL-5 levels determine the response to anti-IL-5 treatment in patients with nasal polyps. J Allergy Clin Immunol. 2006;118(5):1133-41.

9. Gevaert P, Van Bruaene N, Cattaert $T_{\text {, }}$ Van Steen K, Van Zele T, Acke F, et al. Mepolizumab, a humanized anti-IL-5 $m A b$, as a treatment option for severe nasal polyposis. J Allergy Clin Immunol. 2011;128(5):989-95.e1-8.

10. Bachert C, Hellings PW, Mullol J, Naclerio RM, Chao J, Amin N, et al. Dupilumab improves patient-reported outcomes in patients with chronic rhinosinusitis with nasal polyps and comorbid asthma. J Allergy Clin Immunol Pract. 2019;7(7):24479 e2.

11. Jonstam K, Swanson BN, Mannent LP, Cardell LO, Tian N, Wang Y, et al. Dupilumab reduces local type 2 pro-inflammatory biomarkers in chronic rhinosinusitis with nasal polyposis. Allergy. 2019;74(4):743-52.

12. Bachert C, Zinreich SJ, Hellings PW, Mullol J, Hamilos DL, Gevaert P, et al. Dupilumab reduces opacification across all sinuses and related symptoms in patients with CRSwNP. Rhinology. 2020;58(1):10-7.

13. Bachert C, Mannent L, Naclerio RM, Mullo J, Ferguson BJ, Gevaert P, et al. Effect of
Subcutaneous Dupilumab on Nasal Polyp Burden in Patients With Chronic Sinusitis and Nasal Polyposis: A Randomized Clinical Trial. JAMA. 2016;315(5):469-79.

14. Bachert C, Sousa AR, Lund VJ, Scadding GK, Gevaert P, Nasser S, et al. Reduced need for surgery in severe nasal polyposis with mepolizumab: Randomized trial. J Allergy Clin Immunol. 2017;140(4):1024-31 e14.

15. Bachert C, Han JK, Desrosiers M, Hellings PW, Amin N, Lee SE, et al. Efficacy and safety of dupilumab in patients with severe chronic rhinosinusitis with nasal polyps (LIBERTY NP SINUS-24 and LIBERTY NP SINUS-52): results from two multicentre, randomised, double-blind, placebo-controlled, parallel-group phase 3 trials. Lancet. 2019:394(10209):1638-50.

16. Gevaert P, Calus L, Van Zele T, Blomme $K$ De Ruyck N, Bauters W, et al. Omalizumab is effective in allergic and nonallergic patients with nasal polyps and asthma. J Allergy Clin Immunol. 2013;131(1):110-6.e1.

17. Gevaert P, Omachi TA, Corren J, Mullol J, Han J, Lee SE, et al. Efficacy and safety of omalizumab in nasal polyposis: 2 randomized phase 3 trials. J Allergy Clin Immunol. 2020. 146(3):595-605.

18. Hopkins C, Gillett S, Slack R, Lund VJ, Browne JP. Psychometric validity of the 22-item Sinonasal Outcome Test. Clin Otolaryngol. 2009;34(5):447-54.

19. Doty RL, Frye RE, Agrawal U. Internal consistency reliability of the fractionated and whole University of Pennsylvania Smell Identification Test. Percept Psychophys. 1989;45(5):381-4.

20. Lund VJ, Mackay IS. Staging in rhinosinusitus. Rhinology. 1993;31(4):183-4.

21. Higgins JP, White IR, Anzures-Cabrera J. Meta-analysis of skewed data: combining results reported on log-transformed or raw scales. Stat Med. 2008;27(29):6072-92.

22. Clarke M, Horton R. Bringing it all together: Lancet-Cochrane collaborate on systematic reviews. Lancet. 2001;357(9270):1728.

23. DerSimonian R, Laird N. Meta-analysis in clinical trials. Control Clin Trials. 1986;7(3):177-88.
24. Higgins JP, Thompson SG. Quantifying heterogeneity in a meta-analysis. Stat Med. 2002;21(11):1539-58

25. Busse W, Chupp G, Nagase H, Albers FC Doyle S, Shen Q, et al. Anti-IL-5 treatments in patients with severe asthma by blood eosinophil thresholds: Indirect treatment comparison. J Allergy Clin Immunol. 2019;143(1):190-200.e20.

26. Bourdin A, Molinari N. Indirect treatment comparison of asthma biologics fraught with methodology issues. J Allergy Clin Immunol. 2019;143(3):1266-7.

27. Bateman ED, Khan AH, Xu Y, Guyot P, Chao J, Kamat $S$, et al. Response to comment on: Pairwise indirect treatment comparison of dupilumab versus other biologics in patients with uncontrolled persistent asthma (Respir. Med. 2020). Respir Med. 2020:106106.

28. Martin N, Papi A, Bratton DJ, Chan R, Howarth $\mathrm{PH}$, Abbott CB, et al. Comment on: Pairwise indirect treatment comparison of dupilumab versus other biologics in patients with uncontrolled persistent asthma [Respir Med 2020]. Respir Med. 2020:106065.

Peter W. Hellings

Department of Otorhinolaryngology

Head and Neck Surgery

University Hospitals Leuven

Herestraat 49

3000 Leuven

Belgium

Tel: +32-16-33 2342

Fax: +32-16-34 6035

E-mail: Peter.Hellings@uzleuven.be

\section{APPENDIX}

\section{Pubmed search}

("paranasal sinuses"[MeSH Terms] OR ("paranasal"[All Fields] AND "sinuses"[All Fields]) OR "paranasal sinuses"[All Fields] OR "sinuses"[All Fields] OR "sinusal"[All Fields] OR "sinuse"[All Fields] OR "sinusitis"[MeSH Terms] OR "sinusitis"[All Fields] OR "sinusitides"[All Fields] OR ("rhinosinusal"[All Fields] OR "rhinosinusitis"[All Fields]) OR ("nasal polyps"[MeSH Terms] OR ("nasal"[All Fields] AND "polyps"[All Fields]) OR "nasal polyps"[All Fields])) AND ("biolog*"[All Fields] OR ("dupilumab"[Supplementary Concept] OR "dupilumab"[All Fields]) OR ("mepolizumab"[Supplementary Concept] OR "mepolizumab"[All Fields]) OR ("reslizumab"[Supplementary Concept] OR "reslizumab"[All Fields]) OR ("omalizumab"[MeSH Terms] OR "omalizumab"[All Fields] OR "omalizumab s"[All Fields]) OR ("benralizumab"[Supplementary Concept] OR "benralizumab"[All Fields])) combined with “Clinical Trial" 